\title{
ПЛАТИНОНОСНОСТЬ Аu-Аg ФОРМАЦИИ НА ПРИМЕРЕ МЕСТОРОЖДЕНИЯ ВАЛУНИСТОЕ (ЧУКОТСКИЙ АВТОНОМНЫЙ ОКРУГ)
}

\author{
Р. В. Русанов, Ю. Ю. Янникова, Л. Ю. Янникова \\ Воронежский государственный университет
}

Поступила в редакцию 15 ноября 2019 г.

\begin{abstract}
Аннотация: главную промышленную иенность рудного узла Валунистый составляют золото и серебро. Традиџионно считалось, что с Au-Ag формацией платинометальное оруденение не связано. Впервые платиновая минерализация отмечена на месторождении Au-Ag формации Майское Восточно-Сихотэ-Алиньского вулканогенного пояса. Затем самородная Pt была зафиксирована на Au-Ag рудопроявлении Милоградовское. Позднее, на этом же объекте были изучены агрегативные гравитационно-обогатимые зерна платиноидов, полученные путем самосборки при тончайшем измельчении и обработке по особой технологии. В статье приводятся данные рентгеноспектрального микроанализа рудных минералов из тяжелой фракции проб-протолочек и аншлифов рудоносных горных пород. Исследовались минераль сульфидов свинца, железа, ичнка, серебра. Часть проб была проанализирована атомно-абсорбиионным методом. Полученные результаты дают основание пересмотреть рудный потенциал изученного объекта на предмет его платиноносности.
\end{abstract}

Ключевые слова: платиноиды, сульфиды, микрозонд, элементы-примеси, месторождение Валунистое, Au-Ag формацияя.

\section{THE PLATINUM CONTENT Au-Ag FORMATIONS OF THE VALUNISTOE DEPOSIT (CHUKOTSK AUTONOMOUS DISTRICT)}

\author{
R. V. Rusanov, Yu. Yu. Yannikova, L. Yu. Yannikova \\ Voronezh State University
}

Received 15 November 2019

\begin{abstract}
Boulder ore cluster are gold and silver. Traditionally, platinum mineralization was not associated with the Au-Ag formation. For the first time, platinum mineralization was noted in the Mayskoye field of the East Sikhote-Alin volcanic belt of the Au-Ag formation, where platinum minerals were discovered. Then native Pt was recorded on the Au-Ag ore occurrence Milogradovskoye. Later, at the same facility, aggregate gravity-enriched platinum grains were obtained, by selfassembly during the finest grinding and processing using special technology. The article presents the data of x-ray spectral microanalysis of ore minerals from the heavy fraction of sample pro-logs and polished sections of ore-bearing rocks. The minerals of sulfides of lead, iron, zinc, and silver were studied. Some of the samples were analyzed by atomic absorption method. The results obtained give reason to reconsider the ore potential of the studied object for its platinum content.

Key words: platinoids, sulfides, microprobe, impurity elements, Valunistoe deposit, Au-Ag formation.
\end{abstract}

Введение

Факт формирования платинового оруденения в условиях гидротермального процесса в настоящее время установлен на ряде месторождений: Ватерберг в Южной Африке [1], Чудное в приполярном Урале
[2], некоторые рудопроявления в кислых эффузивах Воронежского кристаллического массива. Платинометалльная минерализация в $\mathrm{Au}-\mathrm{Ag}$ формации может быть связана с их тончайшей распыленностью в кварце и адуляре, а также их агрегатах, или нахождением

(C) Rusanov R. V., Yannikova Yu. Yu., Yannikova L. Yu., 2019

Контент доступен под лицензией Creative Commons Attribution 4.0 License.

The content is available under Creative Commons Attribution 4.0 License. 
в самородном виде [3]. Кроме того, платиноиды могут быть сосредоточены и в сульфидах, например, Наталкинское месторождение [4].

Задачей предлагаемого исследования является установление подобного рудного процесса на других Au-Ag объектах. В качестве такого объекта, было выбрано месторождение Валунистое - классический пример месторождения $\mathrm{Au}-\mathrm{Ag}$ формации.

В настоящее время становится очевидным, что наночастицы играют определяющую роль в формировании основного и сопутствующего оруденения при становлении магматических комплексов. Известно, что магматический расплав может являться продуцентом рудного вещества, либо фактором его переотложения во вмещающих породах. При этом происходит самоорганизация металлов от атомов через кластеры и другие наноразмерные частицы, входящие в состав рудных минералов [5]. Примером являются магматические комплексы Среднего и Южного ТяньШаня, характеризующиеся сопутствующей нетрадиционной платиновой и $\mathrm{Ag}-\mathrm{Au}$ минерализацией [6]. В этом случае наноструктуры металлов (платиновой группы и Au-Ag сплавов и других) позволяют использовать их для решения многих геохимических проблем. В частности, проблемы источника рудного вещества, геохимической и металлогенической специализации магматических комплексов, их общей рудоносности и сопутствующей минерализации [7].

Основным полезным компонентом руд месторождения Валунистое является самородное золото и се- ребро. Среди сульфидной составляющей преобладает пирит, доля которого составляет 99,3%. На долю аргентита приходится около $0,6 \%$. В качестве распространенных примесей присутствуют сульфиды: сфалерит, халькопирит и галенит. Реже встречались примеси теллуридов золота и серебра, свинца, висмута и других металлов. [8].

Основной задачей исследования является определение потенциальной платиноносности месторождения Валунистое и возможность пересмотра перспектив его дальнейшего освоения.

\section{Геологическое строение рудного узла}

Валунистый и положение рудоносных тел

Территория расположена в пределах субширотного сегмента Охотско-Чукотского вулканогенного пояса (ОЧВП), представляющего пограничную структуру в области максимального сжатия на северо-восточной окраине Азии, обусловленного расширением Тихоокеанской плиты [9].

Валунистый рудный узел расположен в Канчаланской магмо- и рудоконтролирующей зоне разломов, северо-восточного простирания, на участке пересечения ее разломами субширотного простираний, образующих клиновидные блоки. Амгуэмо-Канчаланское вулканогенное поле расположено на западном замыкании Восточно-Чукотской фланговой зоны ОЧВП, перекрывающем в этом районе Кони-Танюрерскую складчатую систему Корякско-Камчатской складчатой области (рис. 1).

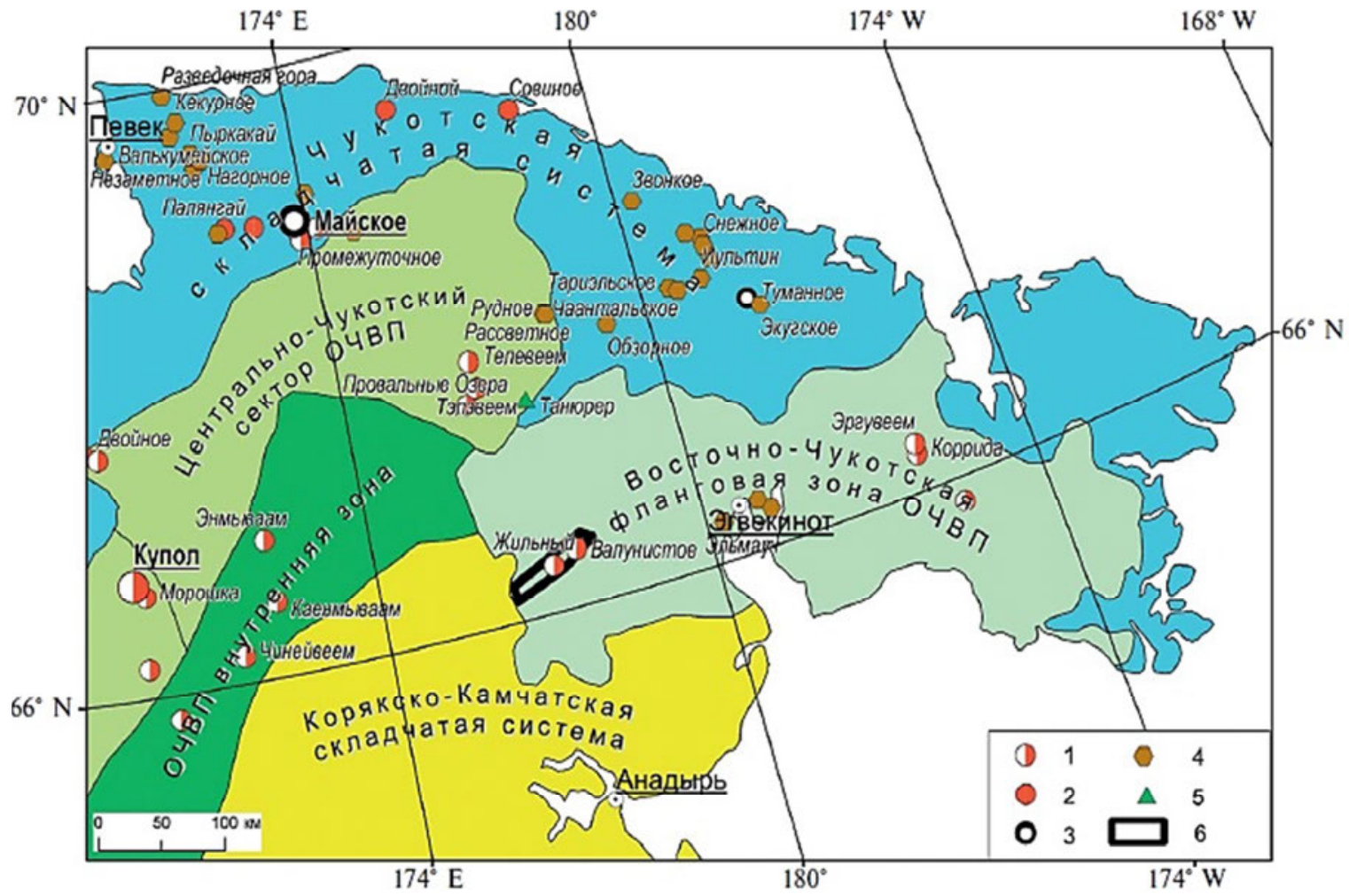

Puc. 1. Положение месторождения Валунистое в региональных структурах, на основе схемы В. Ф. Белого [10]. 1-5 - месторождения: 1 - Au-Ag эпитермальные, 2 - Аu-кварцевые, 3 - Аu-сульфидные, вкрапленные, 4 - оловорудные; 5 - Сu-Мопорфировые; 6 - Амгуэмо-Канчаланская металлогеническая зона. 
Валунистое рудное поле площадью 26 км², приурочено к двум сближенным вулкано-купольным структурам - Валунистой и Шалой, к надинтрузивной части массива леурваамского гранодиорит-гранитлейкогранитового комплекса, вскрывающегося к востоку от месторождения. Рудное поле включает в себя серебряно-золотое месторождение Валунистое, ряд проявлений (уч. Горный, Жильный, Огненный и т.д.) и ряд пунктов минерализации золота и серебра.

В геологическом строении площади рудного поля принимают участие вулканогенные образования позднемелового возраста и рыхлые четвертичные отложения.

По данным геолого-съемочных работ масштаба 1:50000, площадь рудного поля Валунистое представляет собой интрузивно-купольное поднятие на пересечении кольцевой Кытэпнайваамской вулканоплутонической структуры с субширотной АмгуэмоКанчаланской структурно-формационной зоной структур первого порядка [10] (рис. 2).

В разрезе вулканитов картируются породы амгеньской толщи (покровные игнимбриты и туфы риолитов, риодацитов, дацитов, трахириолитов, трахидацитов и субвулканические дациты), экитыкинской и леурваамской свит (игнимбриты, лавы и туфы от риолитового до базальтового состава, субвулканические тела и дайки андезитов, базальтов, дацитов) мощностью до 650-800 м [11].

Вулканические породы в пределах вулкано-купольных структур рудного поля Валунистое, гидротермально изменены до вторичных кварцитов, аргиллизитов и пропилитов. Гидротермалиты вмещают многочисленные кварцевые, адуляр-кварцевые и карбонатные жилы и жильные зоны, часть из которых содержит промышленное золотосеребряное оруденение [12].

В пределах Канчалаго-Амгуэмской площади, большинства рудных полей (месторождение Валунистое, участки Горный, Шах, Жильный) в рассматриваемой формационной зоне, приурочены к вулканокупольным кольцевым структурам. По данным результатов проведенных ранее работ, было отмечено, что наибольшее металлогеническое значение имеют именно интрузивно-купольные и вулкано-купольные структуры, в частности, сопряженные или пересеченные крупными разломами [13]. Разрывные нарушения, относящиеся к структурному парагенезу транспрессионных сдвигов широтного простирания, которые совместно с Канчаланской системой разломов образуют клиновидный тектонический блок, определяют структурное положение рудного узла Валунистый, и входящего в него рудного поля Валунистое. $\mathrm{Au}-\mathrm{Ag}$ рудоносные зоны и жильные тела распределены неравномерно в пределах вулкано-купольных структур. Одни трещины и разрывные нарушения являются дорудными и заполнены дайками трахиандезитов, базальтов, трахидацитов и т.п., другие «пустыми» гидротермалитами, а по третьим развивались рудоносные жилы. Рудоносные жилы связаны с трещинами, сформированными за счет пульсационно- го остывания интрузии в магматической камере, которые близки к углу падения в $60^{\circ}$. Для рудного поля Валунистое основными рудоносными зонами являются: «Главная» В-СВ простирания и «Новая» С-СВ простирания. Кроме того, встречаются многочисленные жильные тела различной ориентировки.

В целом, для рудного узла Валунистый, и прилегающих к нему рудных полей, характерна приуроченность рудных тел к кольцевым интрузивно- и вулкано-купольным структурам, которые можно охарактеризовать как рудоконтролирующие структурные образования.

Руды месторождения являются типичными для золотосеребряных месторождений вулканогенных поясов, хотя и имеют ряд особенностей. Многоэтапный процесс рудообразования связан с внедрением интрузивных и субвулканических тел разного состава. Предрудный этап завершился с внедрением интрузии диорит-гранодиоритового состава. Непосредственно рудные образования, парагенетически и пространственно связаны с субвулканическими телами риодацитов, и тяготеют к экзоконтактовой либо центральной части субвулканов. Петрофизические показатели (пористость, упругость, прочность горных пород) подразумевают различную фильтрационную способность и степень хрупких деформаций, и, следовательно, вероятность наличия рудных тел в тех или иных породах [12]. Субвулканические тела риодацитов, являются наиболее компетентными для рудоотложения, и, как правило, рудоносные тела тяготеют к контактам на границе субвулканитов с другими субвулканическими телами или с туфами. Таким образом, возможна этажность оруденения с наличием не вскрытых эрозией рудных тел, и чередованием различных по составу субвулканических и вулканических тел в разрезе.

Основным полезным компонентом руд является золото и серебро. Остальные металлы ввиду низких содержаний интереса не представляют. Главными породообразующими минералами, слагающими руды месторождения, являются кварц, калиевый полевой шпат (ортоклаз, адуляр) и глинисто-гидрослюдистые минералы (серицит, гидрослюда, каолинит). Постоянно в незначительных количествах отмечаются кальцит, хлорит.

\section{Методика}

Учитывая предполагаемое наноразмерное состояние платиновых минералов, очевидно, что их изучение в рудных минералах при помощи микрозонда не может быть оптимальным инструментарием. Для достоверного определения содержания элементов в минералах при использовании ренгеноспектрального микроанализа их содержания должны превышать погрешность прибора в 2 раза. Исследование образцов проводили при ускоряющем напряжении $\mathrm{U}=20$ кВ. Все образцы были отполированы и покрыты углеродом - толщина (нм): 15,0, плотность (г/см3): 2,25 (Аналитик - Базиков Н. С.). 


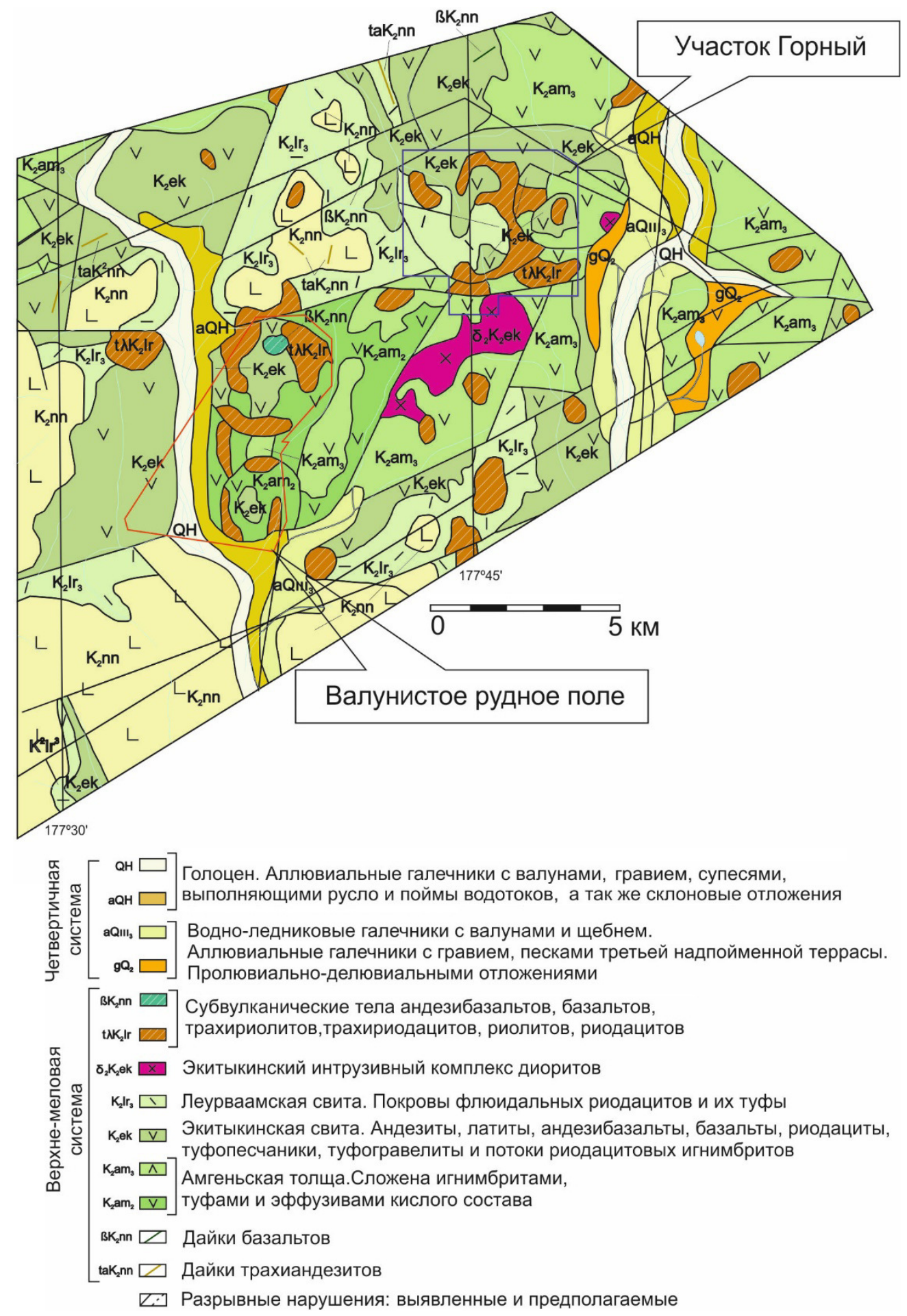

Рuc. 2. Геологическая схема месторождения Валунистое и участка Горный, входящих в состав Амгуэмо-Канчаланской структурно-формационной зоны.

Для исследований рудных минералов рудного поля Валунистое использовались разные типы руд, в том числе: вторичные кварциты, кварц-сульфидные жилы, карбонатные жилы, кварцевые брекчии, кварцевые жилы, кварц-карбонат-флюоритовые жилы, кварц-адуляровые жилы, метасоматиты, отобранные как с самого месторождения, так и с прилегающего к нему перспективного участка Горный. Для анализа были подготовлены пробы-протолочки (после предварительного детального исследования на микроскопе «БиОптик BRP-100»), с последующим обогащением до тяжелой фракции, аншлифы и шлифы.

Часть образцов (10 шт.) были раздроблены вручную. После этого, материал тщательно промывался и обогащался вручную на геологическом лотке. После обогащения получился различный объем тяжелой 
фракции, в зависимости от конкретных типов рудоносных пород. Затем минералы разделялись в бромоформе. Минералы тяжелой фракции исследовались на рудном микроскопе «БиОптик ВRP-100». Поскольку для данного типа месторождения минералы золота и серебра характерны в очень мелком и тонкодисперсном виде (как и для большинства вулканогенногидротермальных типов месторождения) [14, 15] 3олото, серебро и платиноиды в самородном виде «уловить» в лотке не удалось. В основном, это минералы сульфидов свинца, железа, цинка, реже серебра. Для установления взаимосвязей, и возможной ассоциации с золотом, серебром и другими редкими металлами, производились выборки по критериям выветрелости, степени сохранности, различным морфологическим признакам, сонахождения минералов и степени изоморфизма. Далее монофракции рудных минералов были закатаны в минералогические «шайбы». Было проведено 68 рентгеноспектральных микроанализов и сделано около 100 фотографий на растровом электронном микроскопе Jeol 6380 LV с энергодисперсионной системой количественного анализа Inca-250. B статье представлены результаты анализов сульфидов, которые, по предположениям авторов, могут содержать ЭПГ. После обобщения результатов микрозондовых анализов, были выбраны пробы для выявления содержаний Pt методом атомно-абсорбционной спектрометрии (ААС), с использованием платиновой лампы. При этом исходный материал дробился до фракции $-0,1$ мм, отбирались навески по 1 г для растворения в 10 мл царской водки. Растворения проб происходило при $60^{\circ} \mathrm{C}$ в течение 1 часа, и далее при комнатной температуре в течение 6 часов. Затем раствор каждой пробы был отфильтрован и проанализирован на ААС КВАНТ-Z.ЭТА-1.

Микрозондовый и атомно-абсорбционный анализы проводились в центрах коллективного пользования научным оборудованием ВГУ.

\section{Результаты исследования}

Результаты изучения минералов главных типов руд по потенциально платиносодержащим пробампротолочкам и аншлифам месторождения Валунистое представлены на рис. 3 и в таблице 1.

На снимке 1 отмечено мономинеральное зерно галенита кварц-сульфидной жилы, со слабо заметным решетчатым строением, пористое, разрушенное, с признаками выщелачивания. На снимке 2 выделена пирит-галенитовая ассоциация. Порода - кварцевая брекчия. Отмечаются замещения галенита (белый) по пириту (серый), причем галенит развивается как в виде отдельных мелких включений, так и в виде крупных агрегатов и скоплений. Зерна галенита неравномерно распределены в зерне пирита, без видимых изменений структуры самого зерна, и чаще всего, встречаются в трещинках и кавернах пирита, а также в виде каемок обрастания (это хорошо заметно в северной части зерна), что говорит о наложенном характере галенитовой минерализации. На снимке 3 акантит-галенитовая ассоциация из кварцевой жилы. Галенит (белый) отмечен в виде сростков и агрегативных нарастаний, замещающих акантит (светлосерый), и вероятно является более поздним.

Следует отметить, что наиболее характерным минералом, содержащим в себе примеси МПГ может быть галенит. Ранее платиноиды отмечались и в сульфидах жильных гидротермальных образований на контактах с вмещающими углеродсодержащими породами на Наталкинском месторождении [4]. Тем не менее, ряд авторов подтверждают, что минералы платиновой группы отмечали находки минералов платиновой группы в вулканогенно-гидротермальных месторождениях и проявлениях Восточно-СихотэАлиньского Вулканогенного Пояса [16, 17$]$.

Хорошо заметно решетчатое строение и пористость зерна акантита, со структурой замещения. Снимок 4 отображает четырёхкомпонентную сульфидную

Таблица 1

Состав рудных минералов пород месторождения Валунистое по данным рентгеноспектрального микроанализа

\begin{tabular}{|c|c|c|c|c|c|c|c|}
\hline \multirow{3}{*}{$\begin{array}{c}\text { Элемент } \\
\mathrm{S} \\
\end{array}$} & \multicolumn{7}{|c|}{ Весовой/Весовой $\delta, \%$} \\
\hline & \multirow{2}{*}{$\begin{array}{c}\text { Галенит } \\
16,45 / 1,11 \\
\end{array}$} & \multirow{2}{*}{$\frac{\text { Пирит }}{54,69 / 1,04}$} & \multirow{2}{*}{$\begin{array}{c}\text { Галенит } \\
14,06 / 1,12\end{array}$} & \multirow{2}{*}{$\begin{array}{c}\text { Галенит } \\
15,14 / 0,58\end{array}$} & \multicolumn{2}{|c|}{ Полибазит } & \multirow{2}{*}{$\frac{\text { Галенит }}{35,82 / 1,00}$} \\
\hline & & & & & $11,93 / 0,36$ & $12,02 / 0,62$ & \\
\hline $\mathrm{Fe}$ & & $45,51 / 0,76$ & & & & & $27,03 / 0,63$ \\
\hline $\mathrm{Pb}$ & $83,45 / 1,58$ & & $85,38 / 2,51$ & $84,11 / 2,58$ & & $85,36 / 2,80$ & $31,71 / 2,43$ \\
\hline $\mathrm{Cu}$ & & & & & $8,11 / 0,58$ & & \\
\hline $\mathrm{Au}$ & & & & & & $2,50 / 1,44$ & \\
\hline $\mathrm{Ag}$ & & & & & $65,84 / 1,30$ & & $4,19 / 0,54$ \\
\hline $\mathrm{Cd}$ & & & & & $1,82 / 1,04$ & & \\
\hline $\mathrm{Sb}$ & & & & & $9,21 / 0,72$ & & \\
\hline $\mathrm{Se}$ & & & & & $1,57 / 0,58$ & & \\
\hline Сумма & 99,9 & 101,2 & 99,4 & 99,25 & 100,0 & 99,8 & 100,0 \\
\hline $\begin{array}{c}\text { Кристалло- } \\
\text { химическая } \\
\text { формула } \\
\end{array}$ & $\mathrm{Pb}_{0,8} \mathrm{~S}_{1}$ & $\mathrm{Fe}_{0,9} \mathrm{~S}_{2}$ & $\mathrm{~Pb}_{0,9} \mathrm{~S}_{1}$ & $\mathrm{~Pb}_{1} \mathrm{~S}_{1}$ & $\begin{array}{c}\mathrm{Cu}_{2,4} \\
(\mathrm{Ag}, \mathrm{Cu})_{5} \mathrm{Ag}_{12} \\
\mathrm{Cd}_{0,3} \mathrm{Sb}_{1,4} \mathrm{Se}_{0,3} \mathrm{~S}_{11}\end{array}$ & $\mathrm{~Pb}_{1} \mathrm{~S}_{1}$ & $\begin{array}{l}\mathrm{PbS}+ \\
\mathrm{FeS}_{2}\end{array}$ \\
\hline
\end{tabular}



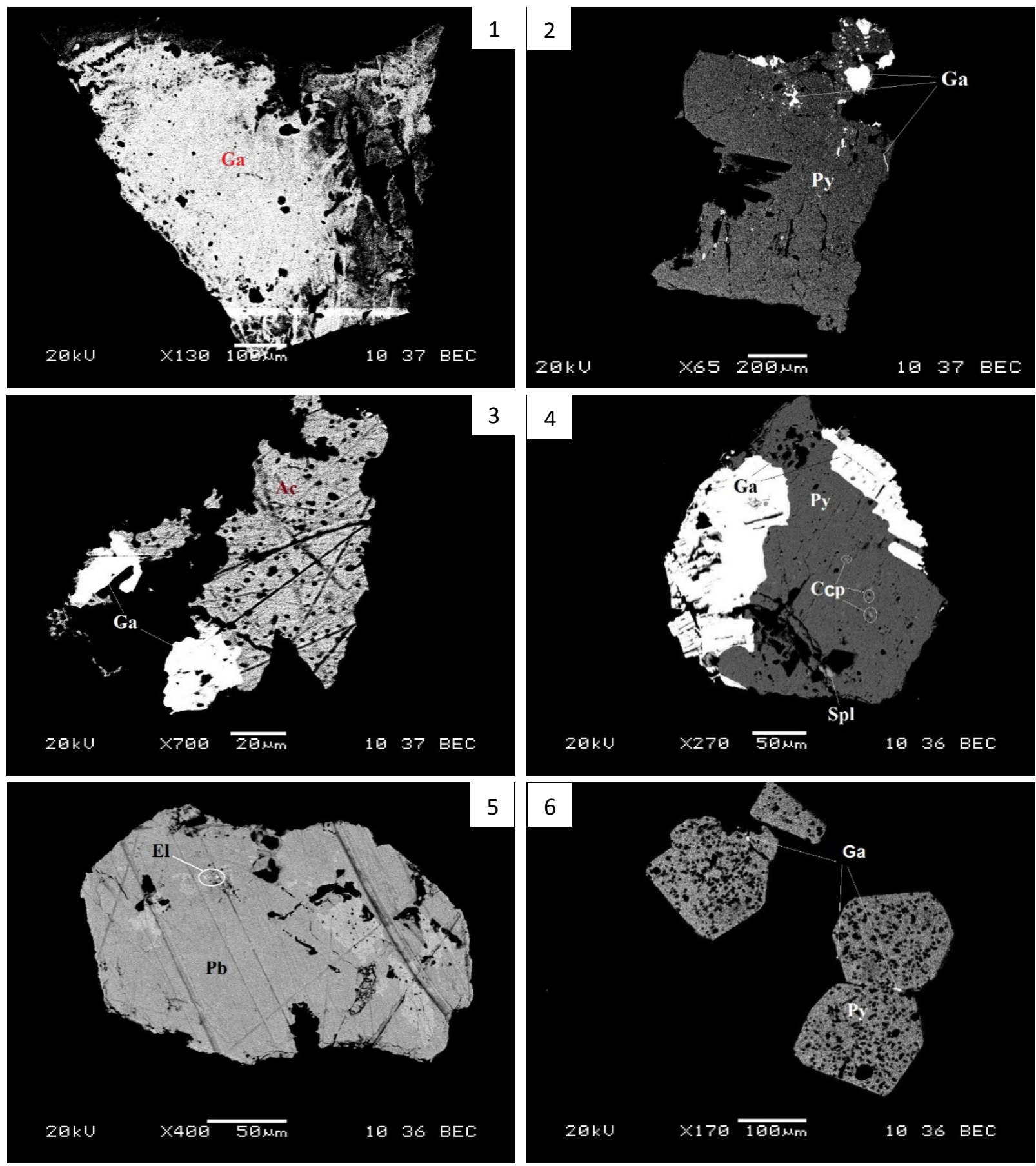

Рис 3. Изображение в отраженных электронах рудных минералов месторождения Валунистое. Цифрами указаны номера образцов руд: 1 -кварц-сульфидная жила; 2 - кварцевая брекчия; 3 - кварцевая жила; 4 - кварц-адуляровая жила; 5 - метасоматит; 6 - вторичный кварцит. Латинскими буквами указаны рудные минералы: $G a$-галенит; $P y$-пирит; Chp - халькопирит; $A c-$ акантит; $S p l$ - сфалерит; $E l$ - электрум; $P b$ - полибазит.

ассоциацию пирит-галенит-сфалеритовую из кварцадуляровой жилы. В идиоморфном зерне пирита (темно-серый) неравномерно распределены мелкие включения халькопирита (серый) в виде отдельных вкрапленников и пятен, локализованных в районах пустот. Вероятно, халькопирит более поздний. Сфалерит (светло-серый) расположен в нижней части зерна в виде отдельного образования, представляющего собой гипидиаморфный агрегат. Псевдоморфозы га- ленита (белый) развиты в виде нарастающих масс по краям зерна пирита, реже в виде мельчайших включений, без изменений структуры самого зерна. Возможно, галенит является самым поздним минералом. На снимке 5 полибазит с включениями электрума (порода - метасоматит). На фото представлена разновидность сульфосоли серебра - полибазит (светлосерый), в котором содержатся очень мелкие включения электрума. Полибазит представлен в виде упло- 
щенной шестиугольной призмы с таблитчатым строением. Отмечаются многочисленные крупные каверны, по краям которых выделен тоже полибазит, но более светлый. Включения в виде зерен электрума при большом увеличении, имеют овально-вытянутые и неправильные формы. На снимке 6 пирит с мелкими включениями галенита. Идиоморфные призмы зерен пирита (серое) сильно кавернозные, вероятно за счет разъедания, с мелкими включениями галенита (белое). Галенит представлен в виде сростка с пиритом в межзерновом пространстве, либо развит по краям каверн в пирите.

Для определения платины в исследуемых образцах, был применен метод атомно-абсорционной спектрометрии (ААС) с использованием платиновой лампы.
Основанием для применения данного метода, послужил факт многократной фиксации МПГ в сульфидсодержащих рудах. Использование метода ААС может с большей степенью достоверности подтвердить наличие платиноидов в исследуемых породах.

В таблице 2 представлены результаты исследований образцов с помощью атомно-абсорбционной спектрометрии.

Породы, содержащие более 10 \% сульфидов в масce (обр. 1, 2, 4), показали различную степень растворимости в царской водке, и различные содержания $\mathrm{Pt}$ от 0,21 до 0,45 г/т. Для кварцевой жилы (обр. 3), в которой содержание сульфидов менее $1 \%$ в массе, характерно содержание Pt 0,50 г/т. Для малосульфидных $(1-3 \%)$ образцов $(5,6)$ характерны наиболее высокие (от 11,8 до 25,9 г/т) содержание $\mathrm{Pt}$.

Таблица 2

Среднее содержание Pt в различных породах месторождения Валунистое

\begin{tabular}{|c|c|c|c|c|c|c|}
\hline $\begin{array}{c}\text { № } \\
\text { обр. }\end{array}$ & Порода & $\begin{array}{c}\text { Вес мате- } \\
\text { риала (г) }\end{array}$ & $\begin{array}{c}\text { Вес нераство- } \\
\text { римого осадка } \\
(г)\end{array}$ & $\begin{array}{c}\text { Количество } \\
\text { раствора } \\
\text { (мл) }\end{array}$ & $\begin{array}{c}\text { Содержание } \\
\text { Рt в растворе } \\
\text { (мкг/л) }\end{array}$ & $\begin{array}{c}\text { Содержание Рt в пере- } \\
\text { расчете на исходный } \\
\text { материал (г/т) }\end{array}$ \\
\hline 1 & Кварц-сульфидная жила & 1,1850 & 1,1346 & 10 & 24,7 & 0,21 \\
\hline 2 & Кварцевая брекчия & 1,1572 & 0,5006 & 10 & 51,5 & 0,45 \\
\hline 3 & Кварцевая жила & 1,0581 & 1,0069 & 10 & 52,0 & 0,50 \\
\hline 4 & Кварц-адуляровая жила & 1,0973 & 0,4629 & 10 & 47,5 & 0,43 \\
\hline 5 & Метасоматит & 1,0670 & 0,8972 & 1000 & 12,6 & 11,8 \\
\hline 6 & Вторичный кварцит & 1,0531 & 0,7480 & 1000 & 27,3 & 25,9 \\
\hline
\end{tabular}

Примечание: каждый образец был проанализирован трижды для выявления среднего показателя. Растворы образцов 5 и 6 были разбавлены в 100 раз [18]. Образцы 5 и 6 были продублированы и повторно проанализированы.

\section{Выводы}

В результате проведенных исследований методом ААС отмечаются значимые содержания Pt в породах месторождения Валунистое. Для установленных конкретных содержаний Pt в породах, необходимо провести систематические исследования многочисленных образцов с применением дополнительных методов для изучения благородных металлов нано-размерного состояния. Применение «кавитационного» дробления для суперизмельчения образцов может быть подходящим вариантом для исследования нано-размерных благородных металлов.

Применение физико-химического метода АAC для изучения вопроса наличия платины в образцах показало его высокую эффективность.

Таким образом, следует пересмотреть ресурсный потенциал $\mathrm{Au}-\mathrm{Ag}$ формации на предмет платиноносности не только рудного узла Валунистый, но и с учетом результатов изучения платиноидов на Милоградовском рудопроявлении, и в Восточно-СихотэАлинском вулканогенном поясе Западно-Тихоокеанского пояса и Дальнего Востока. $[3,17,16]$.

\section{ЛИТЕРАТУРА}

1. Гидротермальное платиновое оруденение месторождения Ватерберг (Трансвааль, Республика Южная Африка) / В. В. Дистлер [и др.] // Геология рудных месторождений. 2000. - T. 42. - № 4. - С. 363-376
2. Новый золото-палладиевый тип минерализации в Кожимском районе Приполярного Урала (Россия) / М. Б. Тарбаев [и др.] // Геология рудных месторождений. - 1996. - Т. 38. - № 1. - С. 15-30.

3. Самосборка нанодисперсных форм платиноидов как метод их извлечения на примере золото-серебряных руд Милоградовского проявления (Приморский край)/ Е. В. Ненахова [и др.]. // Вестник Воронежского государственного университета. Серия: Геология. - 2018. - № 4. - С. 102-106.

4. Золото, платина и палладий в рудах Наталкинского месторождения (Верхне-Колымский регион) / Л. П. Плюснина [и др.] // Докл. РАН. 2003. - Т. 391. - № 3. - С. 383-387.

5. Роль природных кластеров благородных металлов как источника рудного вещества при формировании месторождений / В. Н. Матвиенко [и др.] // Вестник Воронежского государственного университета. Серия: Геология. - 2018. № 3. - С. 36-49.

6. Геохимические наноминеральные парагенезисы благороднометального оруденения Срединного и Южного ТяньШаня / Р. Г. Юсупов [и др.] // Геохимия и рудообразование радиоактивных, благородных и редких металлов в эндогенных и экзогенных процессах. - Улан-Удэ: Изд-во БНЦ СО PAH, 2007. - C. 106-108

7. Индукаев, Ю. В. Металлогенические особенности нетрадиционных благородных и редких металлов. / Ю. В. Индукаев // Современные проблемы геологии и разведки полезных ископаемых. Материалы научной конференции. Томск, 2010. - С. 346-351.

8. Шабалин, В. П. Окончательный отчет о поисковых работах в пределах Валунистого рудного поля 1990-1994 гг. / В. П. Шабалин //стр. 6, 47, 69, 72, 108 (том 1,2). 
9. Бельй, B. Ф. Стратиграфия и структуры ОхотскоЧукотского вулканогенного пояса / В. Ф. Белый. - М.: Наука, 1977. - $171 \mathrm{c}$.

10. Бельй, В. Ф. Геология Охотско-Чукотского вулканогенного пояса / В. Ф. Белый. - Магадан: СВКНИИ ДВО PAH, 1994. $-76 \mathrm{c}$.

11. Жуланова, И. Л. Геохронология и геохронометрия эндогенных событий в мезозойской истории Северо-Востока Азии / И. Л. Жуланова, Т. Б. Русакова, И. Н. Котляр. - М.: Наука. - 2007. - 358 c.

12. Шаповалов, В. С. Признаки единой РМС на примере сложноформационного оруденения (Западная Чукотка) / В. С. Шаповалов // Проблемы рудно-формационного анализа и поисковой минералогии на Северо-востоке России. Магадан: СВКНИИ ДВО РАН. - 1994. - С. 73-82.

13. Полин, В. Ф. Петрология контрастной серии АмгуэмоКанчаланского вулканического поля Чукотки / В. Ф. Полин. - Владивосток: ДВО АН СССР. - 1990. - 228 с.

14. Русанов, Р. В. Черты сходства и различия основных рудоносных зон Милоградовского рудопроявления (Приморский край)/ Р. В. Русанов, Ю. Ю. Янникова // Материалы IV Всероссийской научно-практической конференции «Малышевские чтения». - Старый Оскол. - 2019. - С. 98 101.

ФГБОУ ВО Воронежский государственный университет

Русанов Ростислав Владимирович, аспирант кафедры общей геологии и геодинамики

E-mail: rostislav_rusanov1993@mail.ru

Тел.: + 7 (473) $2 \overline{2} 08682$

Янникова Юлия Юрьевна, аспирант кафедры общей геологии и геодинамики.

E-mail:miss.yannikova@mail.ru

Тел.: +7 (473) 2208682

Янникова Лилия Юрьевна, аспирант кафедры общей геологии и геодинамики.

E-mail: lili.yannikova@mail.ru

Тел.: +7 (473) 2208682
15. Литологические и минеральные особенности элювиально-делювиальных надрудных отложений и проблемы их гравитационного обогащения для извлечения золотосеребряного концентрата (на примере рудопроявления Милоградовское, южное Приморье) / В. М. Ненахов [и др.] // Вестник Воронежского государственного университета. Серия: Геология. - 2017. - № 2. - С. 122-132.

16. Первая находка платиноидов в рудах Майского золотосеребряного месторождения (Дальнегорск, Приморье). / Л. И. Рогулина [и др.] // Вестник ДВО РАН. - 2004. - № 5. С. 94-99.

17. Первые данные о находке самородной платины в породах золотосеребряного рудопроявления Милоградовской вулканоструктуры Южного Приморья (Россия). / В. Г. Сахно [и др.] //Доклады академии наук. - 2014. - Т. 454. № 5 . - C. 570-574.

18. Чегринцев, С. Н. Атомно-абсорбционный. Методические указания к выполнению лабораторных работ по курсу «Физико-химические методы анализа» для студентов IV курса, обучающихся по направлению 240501 «Химическая технология материалов современной энергетики». Издательство Томского политехнического университета, 2014. $44 \mathrm{c}$.

\section{Voronezh State University}

Rusanov R. V., postgraduate student, Department of General Geology and Geodynamics

E-mail: rostislav_rusanov_1993@mail.ru

Tel.: +7 (473) 2208682

Yannikova Yu. Yu., postgraduate student, Department of General Geology and Geodynamics

E-mail:miss.yannikova@mail.ru

Tel.: +7 (473) 2208682

Yannikova L. Yu., postgraduate student, Department of General Geology and Geodynamics

E-mail: lili.yannikova@mail.ru

Tel.: +7 (473) 2208682 